\title{
PERIPHERAL NERVE INJURY IN SPORTS
}

\author{
Borislav Radić ${ }^{1}$, Petra Radić ${ }^{2}$ and Din Duraković ${ }^{3}$ \\ ${ }^{1}$ Department of Neurology, Zagreb University Hospital Centre, Zagreb, Croatia; ${ }^{2}$ School of Medicine, \\ University of Zagreb, Zagreb, Croatia; ${ }^{3}$ School of Medicine, University of Rijeka, Rijeka, Croatia
}

SUMMARY - Peripheral nerve injuries in sports are rare. Peripheral nerve injuries in sports are caused by pressure, stretching, or bone fracture. Peripheral nerve injuries are more frequent on upper limbs, and the type of injury is determined by the type of sport. According to Seddon, we distinguish 3 levels of injury: 1) neurapraxia; 2) axonotmesis; and 3) neurotmesis. Diagnosis must be reached as early as possible to enable timely initiation of appropriate treatment. The diagnostics of peripheral nerve injuries includes electromyography and nerve conduction studies, somatosensory evoked potentials, magnetic resonance imaging, and ultrasound. Proximal nerve injuries have a poorer prognosis for neurologic recovery.

Key words: Sports; Peripheral nerve injuries; Diagnosis; Fractures, bone; Trauma, nervous system

\section{Introduction}

Peripheral nerve injuries occur during sports training or competition. According to Hirasawa and Sakakida, peripheral nerve injury accounts for less than $0.5 \%$ of sports-related injuries ${ }^{1}$, while the prevalence of peripheral nerve injuries is $1.3 \%-2.8 \%$ beyond sports activities ${ }^{2}$. Peripheral nerve injuries can be presented with sensory, motor or function disorder. Nerve injuries are categorized as neurapraxia, axonotmesis and neurotmesis ${ }^{3}$. Neurapraxia as temporary rupture of the nerve impulse delivery occurs with nerve demyelination at the site of injury without rupture of nerve continuity. Complete recovery is achieved upon remyelination, which can take up to 12 weeks. Axonotmesis is rupture of axon and degeneration distal from the site of injury and proximal to the next Ranvier's node. Regeneration of the axon proceeds from the site of injury to peripheral organs, at a rate of $1 \mathrm{~mm} /$ day. Neurotmesis is complete interruption of nerve continuity without the possibility of spontaneous function recovery.

Correspondence to: Borislav Radic, $M D, P h D$, Department of Neurology, Zagreb University Hospital Centre, Kišpatićeva 12, HR-10000 Zagreb, Croatia

E-mail: boris.radic105@gmail.com

Received August 24, 2016, accepted February 2, 2017
Peripheral nerve injury is classified as acute, subacute and chronic. Acute injuries are the result of immediate compressive, stretch or laceration forces applied to the nerve. Subacute and chronic nerve injuries are the result of overuse injuries. Overuse injuries is a term used for a variety of conditions that cause discomfort or pain in the muscles, joints, tendons, nerves and soft tissues of the human body. Overuse injury develops as a result of numerous factors such as constant repetition of one and the same movement, permanent muscular contraction or strain, and violent movements; thus, the overuse syndrome is referred to as a gradual injury process ${ }^{4}$. The mechanism of overuse injury development includes athletic training regimen, relevant equipment, and periodization. The term periodization means systematic training planning with cyclic peak performance in training and with appropriate rest ${ }^{5}$.

\section{Diagnosis}

The diagnosis of peripheral nerve injuries is based on history and clinical examination with good knowledge of the anatomy of the specific body regions. It is very important to define the location of the injury, so that sensory and motor damage can be distinguished. 
Acute peripheral nerve injury is usually the result of a direct mechanical action such as stretching due to dislocation or bone fracture, and laceration. Subacute and chronic injuries are the result of repetitive stretching due to articular-muscular structure disorders. Needle electromyography (EMG) and nerve conduction studies are important for distinguishing the main types of damage, as follows: complete loss of axons (neurotmesis); partial loss of axons (axonotmesis); and demyelination (neurapraxia). In case of neurotmesis, there is complete discontinuation of the peripheral nerve continuity, autonomic denervation, and severe damage to vasa nervorum. In case of axonotmesis, there is complete muscle denervation along with the preserved nerve continuity and part of the autonomic fibers and neural microvascularization. In case of neurapraxia, there is functional block of the conduction due to demyelination; spontaneous recovery is a rule but is enhanced by physical rehabilitation. Differentiation of axonotmesis and neurotmesis is based on careful clinical examination. We differentiate degenerative and regenerative phases. In the degenerative phase, within 100 hours, gradual reduction of the evoked muscle response and loss of irritability in distal parts of the nerve occur. The motor and sensory velocities are normal until the complete loss of the compound motor action potential (CMAP). Spontaneous activity of the type of fibrillation occurs after 3-4 weeks on the hands but later on the feet ${ }^{6}$. In the regenerative phase, regenerative shoots without myelin capsule are produced and their conductivity is less than $5 \mathrm{~m} / \mathrm{second}$. The threshold of irritability is exceptionally high (20 to 100 times higher than the proximal part). The speed of regeneration is $1-3 \mathrm{~mm}$ per day. In case of partial nerve injury, regeneration is faster. Owing to collateral reinnervation, the compensatory activity of the fast repetitive potentials is recorded already after 10-14 days. After 2-3 months, depending on the length of the distal segment, reinnervation potentials are recorded. In proximal peripheral nerve lesions, especially in brachial and lumbar plexus and lateral femoral cutaneous nerve, somatosensory evoked potentials may be additionally used. In acute nerve injuries, magnetic resonance imaging (MRI) can provide important data for making a decision on surgical treatment. MRI may show early damage to peripheral nerve, whereas EMG cannot. In case of subacute and chronic injuries, the second cause of nerve damage can also be detected (nerve tumor, cyst $)^{7}$. Ultrasound is a method that is rarely used and can provide data on the dynamic connection of the nerve and joint during movement ${ }^{8}$.

\section{Clinical Presentation}

\section{Spinal accessory nerve injury}

The spinal part of accessory nerve is the motor nerve. The external brunch innervates trapezius and sternocleidomastoid muscles. It lies in the region of the neck, superficially, just behind the scalene muscles. Because of the surface position, it is exposed to direct impact damage (Fig. 1). Acute injuries occur in contact sports such as judo, karate, kickboxing, football, lacrosse and hockey. Motility weakness is not involved in sternocleidomastoid muscle because nerve injury is usually below the innervation site. Motor weakness persists for about 3 months. Initial treatment includes physical therapy to maintain motor skills. If there is no recovery after 6 weeks, it is necessary to do needle EMG with nerve conduction studies. The reinnervation potentials can be found in trapezius muscle. If there are no reinnervation potentials and no motor recovery, surgical treatment is required. The athlete returns to sports training only after full normalization of shoulder function?

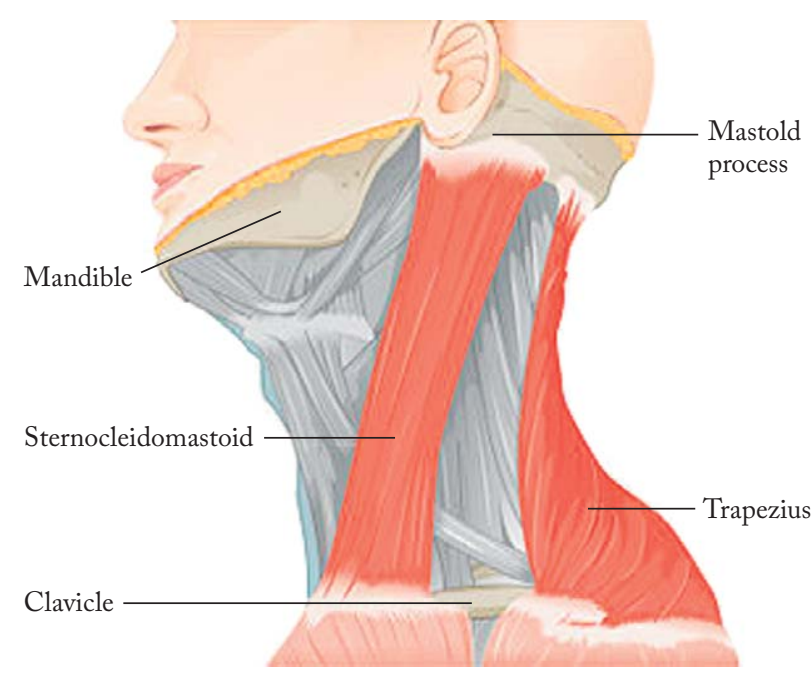

Fig. 1. Accessory nerve - damage.

\section{Long thoracic nerve injury}

The long thoracic nerve is formed by fusion of the C5 and C6 spinal roots. It moves laterally from the 
brachial plexus to the clavicle and runs down along the anterolateral chest wall where with many branches it innervates the anterior serratus muscle. Due to partial superficial exposure, it can be injured in the action of acute force. The most common injury occurs after chronic recurring heavy shoulder strains in sports such as archery, bodybuilding, judo, karate, tennis, volleyball, wrestling and golf'. Clinical finding is typical, i.e. the 'winged scapula'; because of muscular weakness, the scapula lifts up and moves upwards and laterally (Fig. 2). Because of the scapula shifts, abduction in the shoulder above the horizontal is disabled. EMG and nerve conduction studies find neurogenic lesion in the anterior serratus muscle. Treatment is long-term physical therapy. Recovery is expected within 2 years.

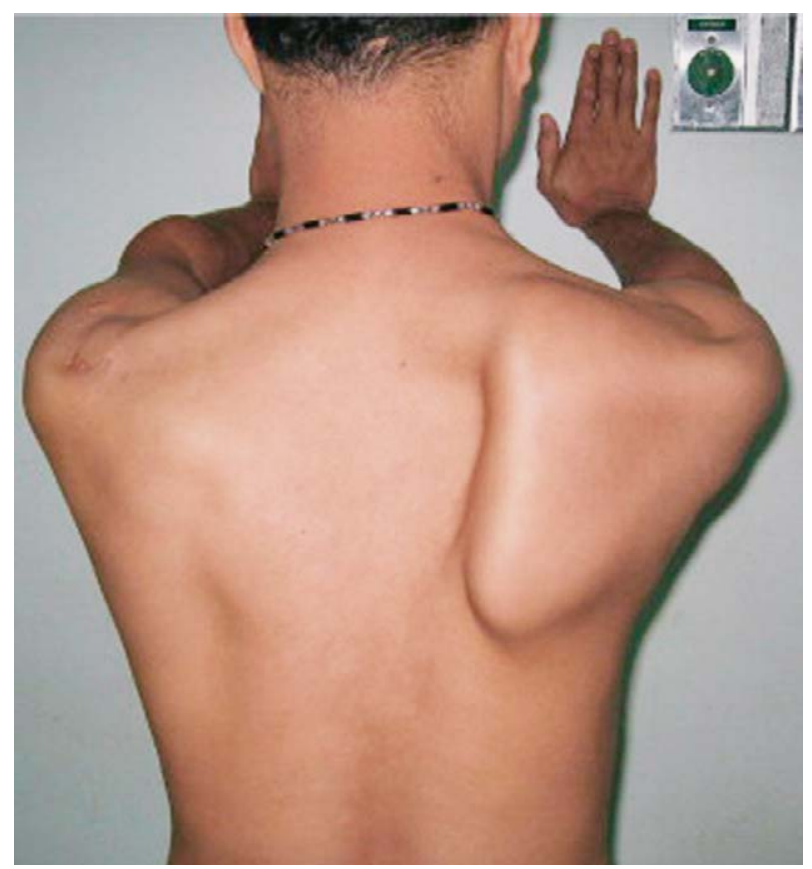

Fig. 2. Long thoracic nerve - 'winged scapula'.

\section{Suprascapular nerve injury}

The suprascapular nerve arises from the C5 and C6 roots through the upper trunk of the brachial plexus and is a mixed sensory-motor nerve. The motor branch innervates the supraspinous and infraspinous muscles (Fig. 3). Rarely, the nerve is injured in acute mechanical action. The nerve is most commonly injured by recurrent hyperabduction movements in the shoulder, especially in the athletes playing baseball, volleyball and tennis. Clinical picture is characterized by pain in the shoulder, and examination can reveal weakness, often with atrophy of the infraspinous and sometimes supraspinous muscle. EMG and nerve conduction studies show selective denervation in the supraspinous or infraspinous muscle, or both. In the diagnosis, we use ultrasound and MRI, which can provide data on other causes of damage. Treatment includes rest and physical therapy ${ }^{10}$. Operative treatment is indicated for refractory cases.

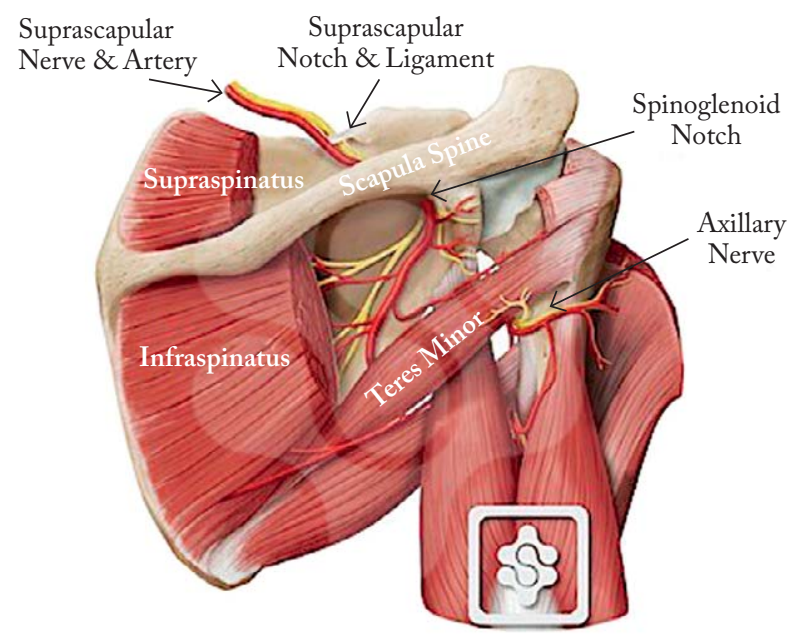

Fig. 3. Suprascapular nerve - anatomy.

\section{Axillary nerve injury}

The axillary nerve arises from the posterior cord of the brachial plexus and contains fibers of the $\mathrm{C} 5$ and C6 roots. The nerve lies laterally from the radial nerve, runs laterally and passes under the shoulder joint and goes to the deltoid muscle. The most common axillary nerve damage is acute trauma, usually associated with fracture or dislocation of the humerus (Fig. 4). The
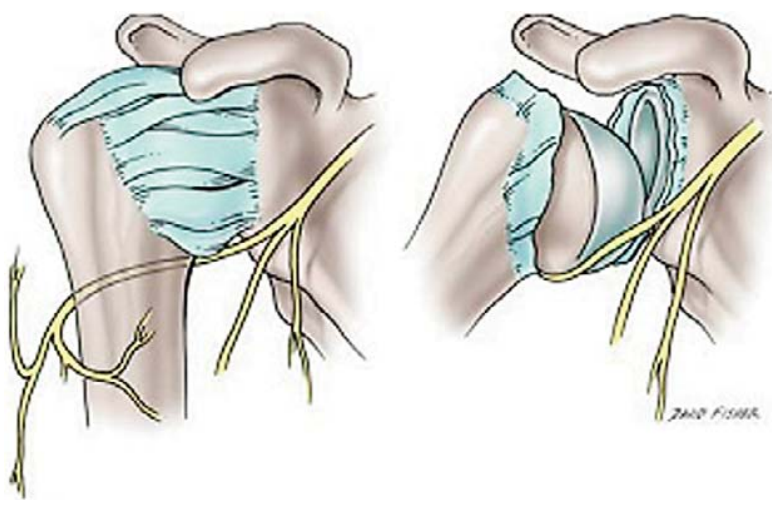

Fig. 4. Axillary nerve-damage. 


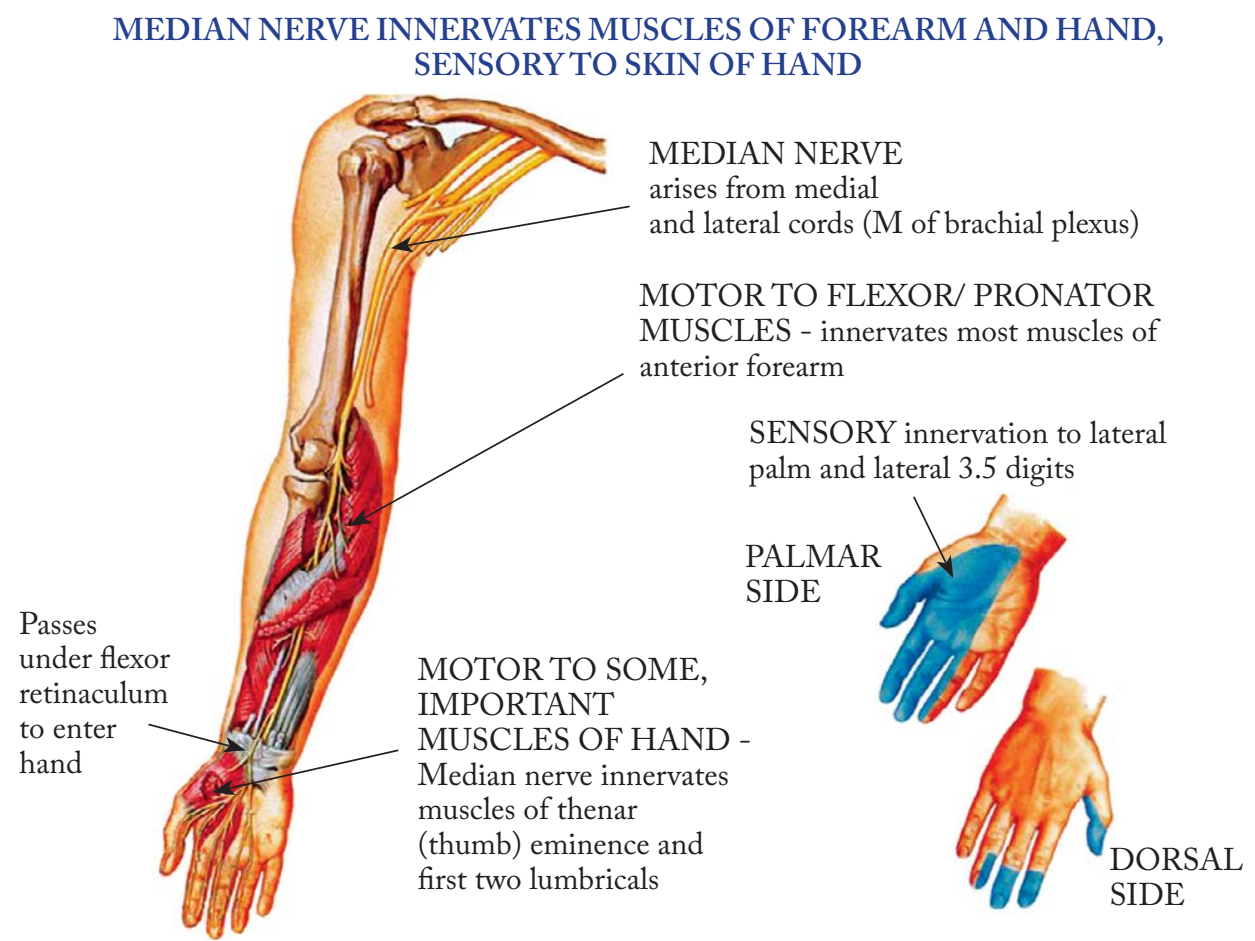

Fig. 5. Median nerve-anatomy.

nerve damage makes abduction of the arm difficult or impossible ${ }^{10,11}$. Atrophy of deltoid muscle and sensation impairment occur. Partial nerve damage is treated by physical therapy and complete damage by surgical intervention. The athlete returns to the training regimen after full recovery.

\section{Median nerve injury}

The median nerve arises from the lateral and medial cord of the brachial plexus and surrounds the lower part of the axillary artery. It runs down the upper arm, lying sideways from the brachial artery and the brachial muscle separates it from the elbow. In the forearm, the median nerve passes between the two heads of the pronator teres muscle. It runs down below the superficial flexor muscle of fingers, lying on the deep flexor muscle of fingers, up to about $5 \mathrm{~cm}$ from the transverse carpal ligament, and then passing behind the transverse carpal ligament on the palm of the hand. On the upper arm, the median nerve does not provide motor innervation but provides sympathetic fibers for the walls of the brachial artery. On the forearm, the median nerve innervates most of the flexors. On the palm, the median nerve innervates thenar muscles. Sensory branches innervate the palmar aspect of the hand, including the first three digits (Fig. 5).

Pronator teres syndrome is one of the three common median nerve entrapment syndromes. Pronator teres syndrome has been described in archery, baseball, weightlifting and racket sport. The median nerve compression is usually the result of excessive and repetitive movements in the elbow and forearm. The median nerve is compressed by two heads of the pronator teres muscle. Clinical symptoms are pain in the volar area of the forearm, especially on pronation motions. There is pain over the pronator teres, and weakness of the flexor pollicis and abductor pollicis brevis is less common. EMG and nerve conduction studies show mild slowing of motor velocity to the proximal part of the forearm with normal distal latency and sensory potential parameters recorded on the wrist ${ }^{12}$. Dynamic ultrasound imaging can help localize the site of compression. Treatment is physical therapy. Sometimes pain can be reduced by the use of corticosteroids and anesthetics. Resistant cases include surgical intervention.

Carpal tunnel syndrome is the most common compressive syndrome of the arm. It is the result of strong pressure in the wrist and is most commonly found in 
cycling, archery, bodybuilding, weightlifting, wrestling, golf and tennis. The first clinical signs are paresthesia, later hypoesthesia and anesthesia, and the appearance of trophic changes. The pain spreads in the palm, sometimes in the forearm, and is strongest in the night. Motor disturbances occur later as insecurity in catching with thenar muscle hypotrophy. EMG and nerve conduction studies show slowing of sensory velocity in the palm and second finger. Distal latency is prolonged and motor velocity is normal or slightly slower ${ }^{13}$. Treatment includes physical therapy, sometimes using corticosteroid injection in the carpal tunnel space. Surgical decompression of the carpal tunnel is indicated in refractory cases.

\section{Ulnar nerve injury}

The ulnar nerve is a mixed nerve (C8-T1). With its motor fibers it innervates the muscles of the forearm and fingers, and with sensory fibers it innervates the skin of finger $\mathrm{V}$ and part of finger IV. The most common damage to the ulnar nerve is in the area of the elbow (Fig. 6). The ulnar nerve can be injured by a direct blow to the back of the elbow in contact sports.

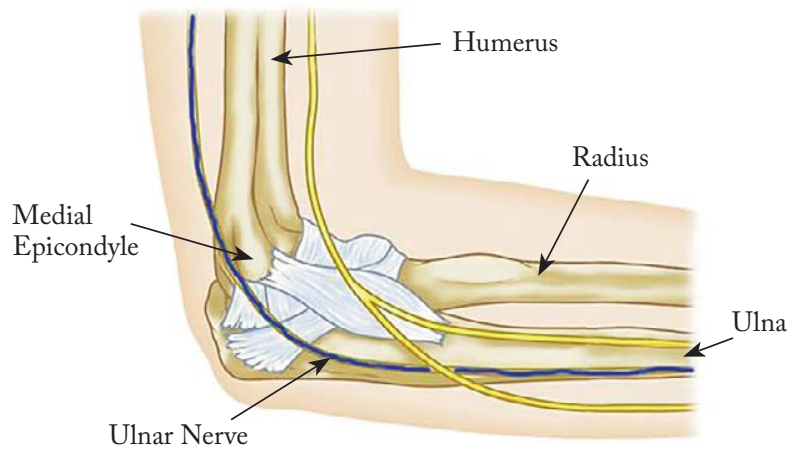

Fig. 6. Ulnar nerve-entrapment at the elbow.

More commonly, ulnar nerve is damaged by compressive forces at the elbow ${ }^{11}$. Clinical signs include paresthesia, hypoesthesia to anesthesia, and pain in the innervation area of the ulnar nerve. Later, there is hypotrophy of the dorsal interosseus and the hypothenar muscles. EMG and nerve conduction studies show slowing of motor velocity in the elbow segment, and reduction of the sensory nerve action potential on the hand and later slowing of sensory velocity. Dynamic ultrasound can show the ulnar nerve subluxation or compression at the elbow. Treatment includes rest and functional rehabilitation. Sometimes the use of corticosteroids and anesthetic injections may alleviate the symptoms. Surgical transposition or decompression of the ulnar nerve is indicated in refractory cases. The second place of compression of the ulnar nerve is on the hand (Guyon's canal syndrome). This is a direct compressive injury in wheelchair athletes, cyclists, crosscountry skiers and snowmobilers. Treatment includes physical therapy, supportive braces or specialized gloves during training and competition.

\section{Radial nerve injury}

The radial nerve is formed from the posterior cord of the brachial plexus. The radial nerve descends from the axillary region, traverses the humerus spirally through the sulcus radialis and gives the motor branch for the triceps brachii muscle. It is lowered on the forearm where it gives motor branches for the extensor muscle group. The radial nerve provides sensory innervation to the dorsal part of the upper arm and forearm, and radial part of the palm ${ }^{14}$.

The radial nerve is most often damaged in the radial sulcus on the upper arm. In athletes, it most commonly occurs as a result of excessive and repetitive elbow extension (racket sports, tennis). Clinical signs are weakness of the extensor muscles of the hand and weakness of the brachioradialis muscle with preserved function of the triceps brachii muscle. Sensory damage affects the skin of the dorsolateral hand. EMG and/ nerve conduction studies show spontaneous denervation activity after 14 days. Motor velocity can be slower on the upper arm (Erb's point). The first signs of recovery are reinnervation potentials in the brachioradialis muscle. The posterior interosseous nerve can be pressed when passing through the two strata of the supinator muscle (Fig. 7). The function of the brachioradialis and extensor carpi radialis muscles is preserved. Clinical sign is deep pain in the back of the forearm with gradual development of weakness of the fingers. Treatment includes rest and physical therapy, whereas surgical intervention is indicated in refractory cases.

\section{Lateral femoral cutaneous nerve injury}

The lateral femoral cutaneous nerve arises from the spinal roots L2 and L3. The nerve passes under the ilioinguinal ligament and provides sensory innervation of the lateral half of the thigh (Fig. 8). Lateral femoral 


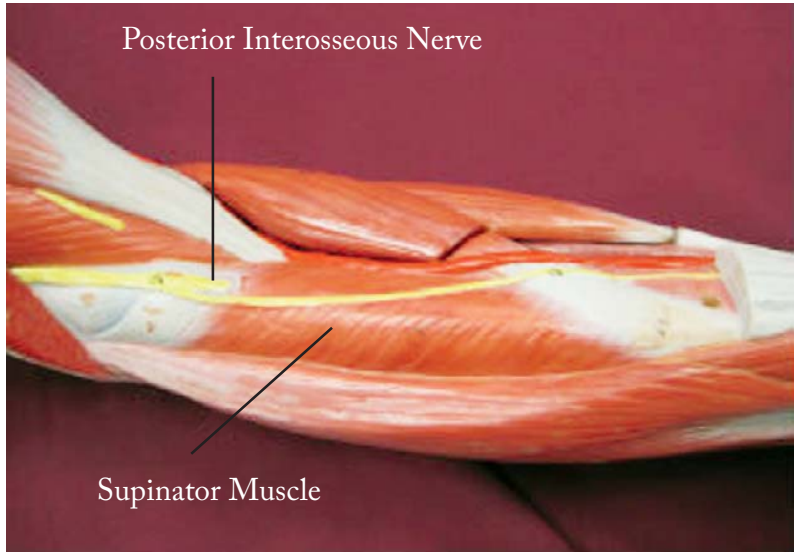

Fig. 7. Radial nerve - supinator syndrome.

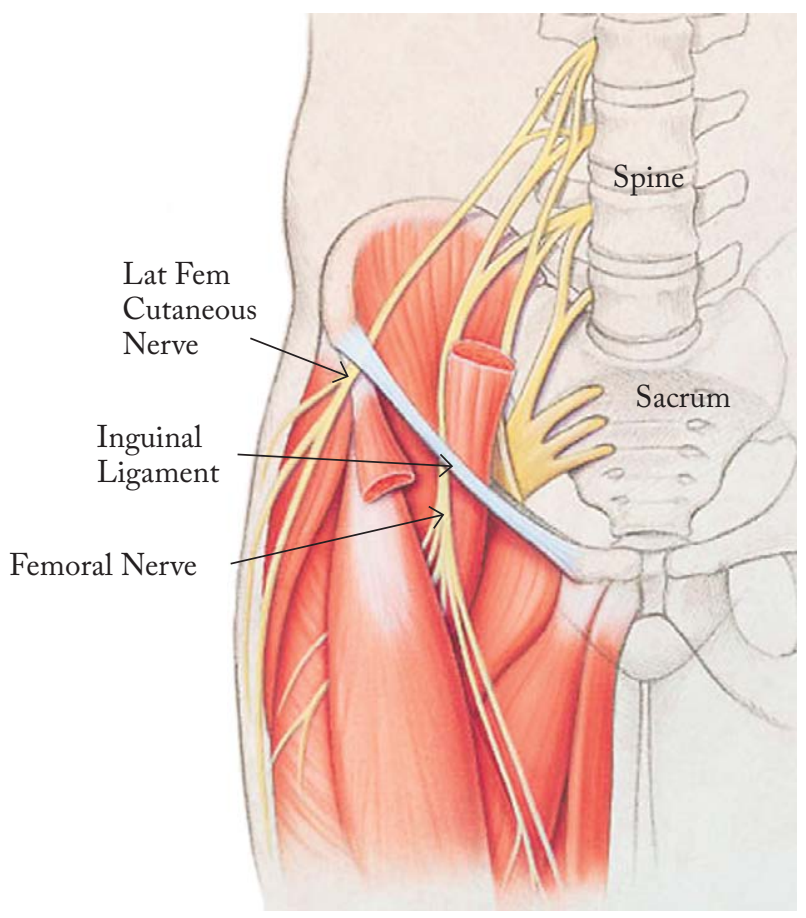

Fig. 8. Lateral femoral cutaneous nerve - anatomy.

cutaneous nerve can be damaged in contact sports (football and rugby), jumping sports (gymnastics with repetitive flexion and extension in the hip), or with compression from external gear (scuba diving) ${ }^{15}$. Clinical signs include pain, paresthesia and numbness of the lateral half of the thigh. The symptoms are most pronounced during the night. EMG and nerve conduction studies are difficult to perform due to the high nerve variability. EMG findings in the quadriceps femoris and clinical signs confirm the diagnosis. Somatosensory evoked potentials may indicate a periph- eral delay. In the treatment of pain, we use analgesics, antidepressants and anticonvulsants ${ }^{16}$. The use of corticosteroids can sometimes alleviate the symptoms. With regard to certain sports, it is necessary to change the way of training and using sports equipment.

\section{Femoral nerve injury}

The femoral nerve arises from the spinal roots L2, L3 and L4 of the lumbar plexus. Motor innervation is provided to the iliopsoas and quadriceps muscles. Sensory innervation includes anterior and medial thigh and anterolateral legs below the knee (saphenous nerve) (Fig. 9). Acute femoral nerve injury occurs during collision, often with hyperextension (gymnastics, football, dancing, long jumping, basketball, ballet dancing, bodybuilding, cross-country skiing). Clinical signs include inguinal pain, thigh numbness and leg weakness. The knee reflex is absent and atrophy of the quadriceps is visible. The knee moves inside and socalled 'genu recurvatum' occurs. It is difficult to stand up. The loss of sensation is on the front of the thigh. EMG and nerve conduction studies show increased femoral nerve latency, reduced amplitude of compound muscle activity potential, and evidence for denervation in the quadriceps femoris ${ }^{17}$. The femoral nerve damage is traumatic; in the diagnosis, we use MRI of the pelvis to prove the possible hemorrhage of the iliopsoas muscle and surgical treatment.

\section{Peroneal nerve injury}

The common peroneal nerve (L4-S2) is a smaller branch of the sciatic nerve. From the upper corner of the popliteal fossa, it runs along the median edge of the biceps femoris and passes around it. The nerve goes around the neck of the fibula and comes to the lateral part of the lower leg. It is divided into two branches, superficial peroneal nerve and deep peroneal nerve. The common peroneal nerve innervates the front and lateral muscle group in the lower leg and foot muscles. The common peroneal nerve innervates with sensory fibers the skin of the anterolateral side of the lower leg and top of the foot (Fig. 10).

The common peroneal nerve injury in sports can develop as an acute traumatic event or as overuse injury (Fig. 10). Because of its superficial position, the nerve is subject to blunt trauma, especially in sports such as hockey, soccer and football. Clinical signs are sudden 

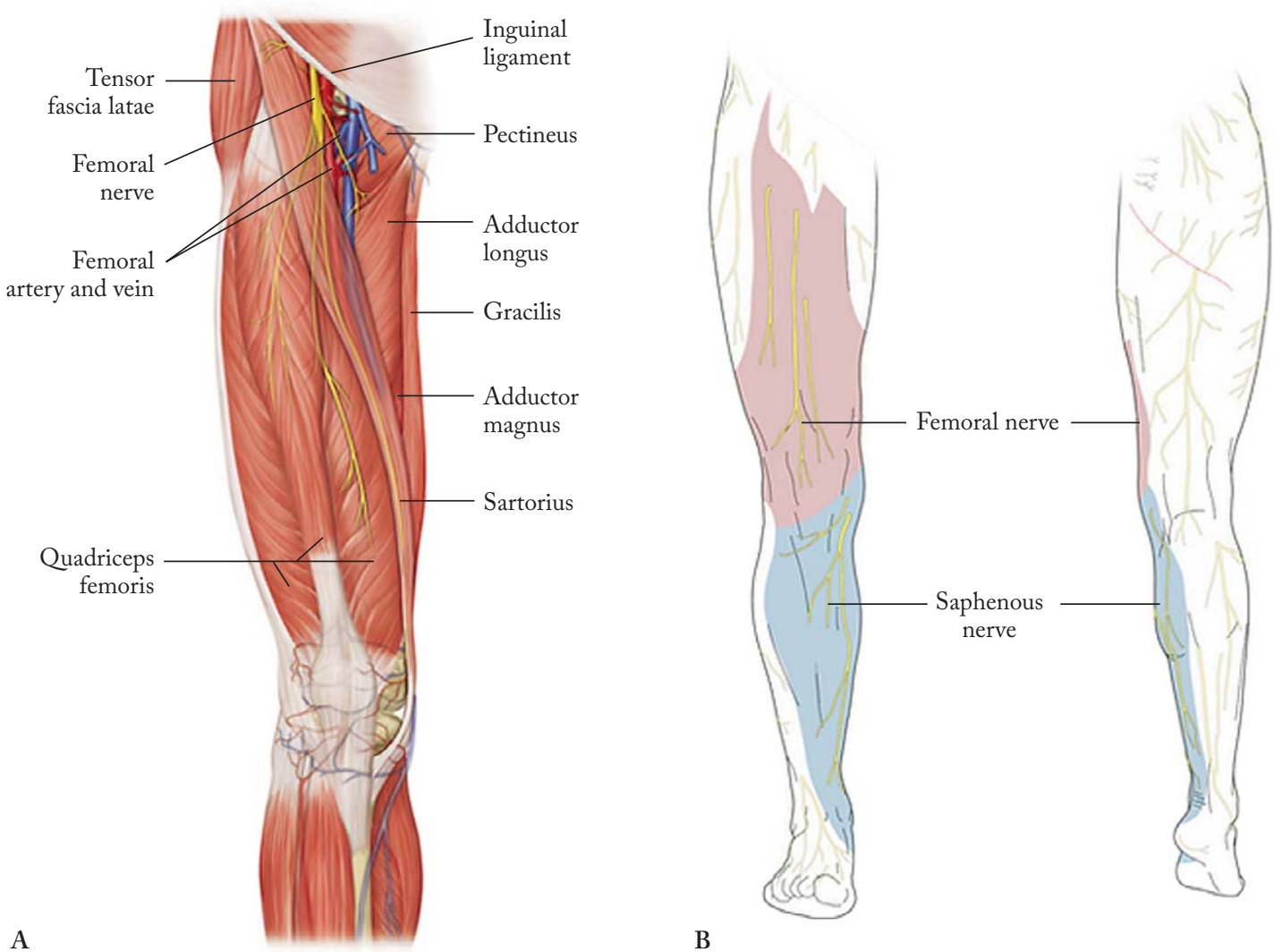

Fig. 9. Femoral nerve - anatomy.

numbness in the foot and partial or complete foot drop. In many cases, the activation of mechanical forces causes transient weakness of the foot that recovers within a few minutes (damage to the level of neurapraxia). The common peroneal nerve may be injured upon the knee or ankle injury when nerve strain occurs, causing foot pain and weakness. EMG and nerve conduction studies should be obtained at 3-4 weeks of the injury, demonstrating slowing of motor velocity. The choice of treatment is physical therapy. A special form of the peroneal nerve injury occurs in runners ${ }^{19}$. The nerve can be compressed by the muscle fascia. Athletes usually have no symptoms at rest or walking but pain, paresthesia and foot drop develop on running. EMG and nerve conduction studies are performed before and after running and can prove nerve entrapment. Sometimes fasciotomy can alleviate the problems. Increase in the hydrostatic pressure in closed osteofascial space results in reduced perfusion of the muscle and nerves within the compartment ${ }^{20}$. Such a pathophysiological process occurs in the lower leg region, especially in runners. Clinical signs are pain and paresthesia in the front or lateral side of the lower limb, which gradually worsen with prolonged running. Sometimes, the runners develop foot weakness. Diagnosis involves careful history, and pre- and post-traumatic examination. EMG and nerve conduction studies are performed as follows: at 1 hour - normal conduction; 1-4 hours - neurapraxic damage reversible; and 8 hours - axonotmesis and irreversible change. Treatment includes rest and recovery from running, but sometimes it can require fasciotomy ${ }^{21}$. The deep peroneal nerve can be injured in the area of crossing from the ankle to the foot. This can usually be seen in skaters and skiers when inappropriate sports equipment compresses the nerve in the ankle area. The nerve damage is at the level of neurapraxia and passes without consequences after proper adaptation of sports equipment.

\section{Tibial nerve injury}

Tibial nerve is a branch of the sciatic nerve. It separates in the knee area. It arises from the spinal roots L4 to S1. The tibial nerve innervates the muscles of the 


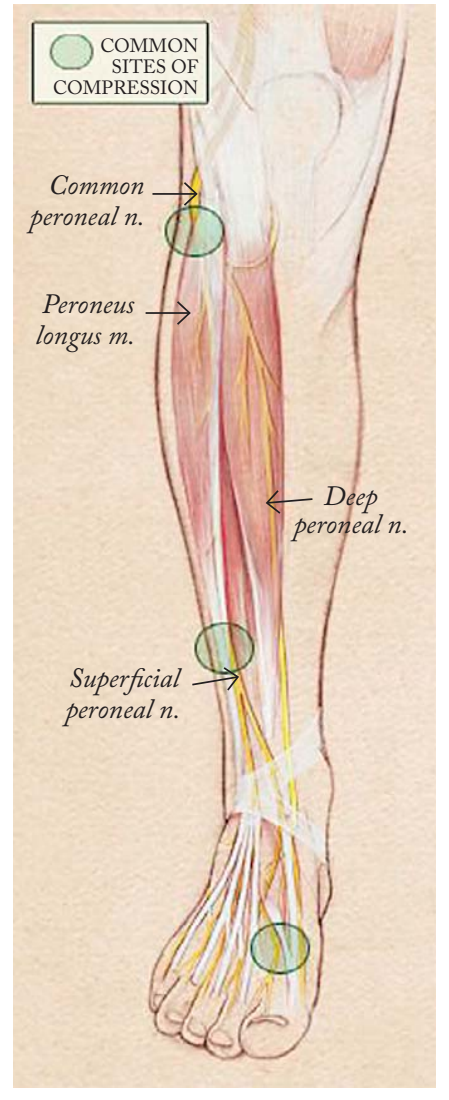

Fig. 10. Peroneal nerve - anatomy and common sites of compression. back of the lower leg and the sole of the foot (Fig. 11). The tibial nerve injury can be caused by compression in the tarsal tunnel or upon ankle injury. Tarsal tunnel is a bone tunnel where the posterior tibial nerve can be strangulated ${ }^{22}$. Clinical signs are pain and paresthesia in the median part of the sole of the foot, tingling in the area of the thumb, more often at night and after long standing, walking or running. Tarsal tunnel syndrome is difficult to diagnose because athletes have normal examination. EMG and nerve conduction studies show prolonged distal latency in the flexor hallucis brevis muscle and reduction of the CMAP. The values of sensory velocity are highly variable. In the treatment, analgesics, rest and sometimes injections of corticosteroids are used. In refractory cases, neurolysis can reduce the symptoms ${ }^{23}$.

\section{Pudendal nerve injury}

The pudendal nerve arises from the spinal roots S1-S4. The pudendal nerve innervates external genitalia of both sexes and the skin around the anus and perineum. The pudendal nerve entrapment (Alcock

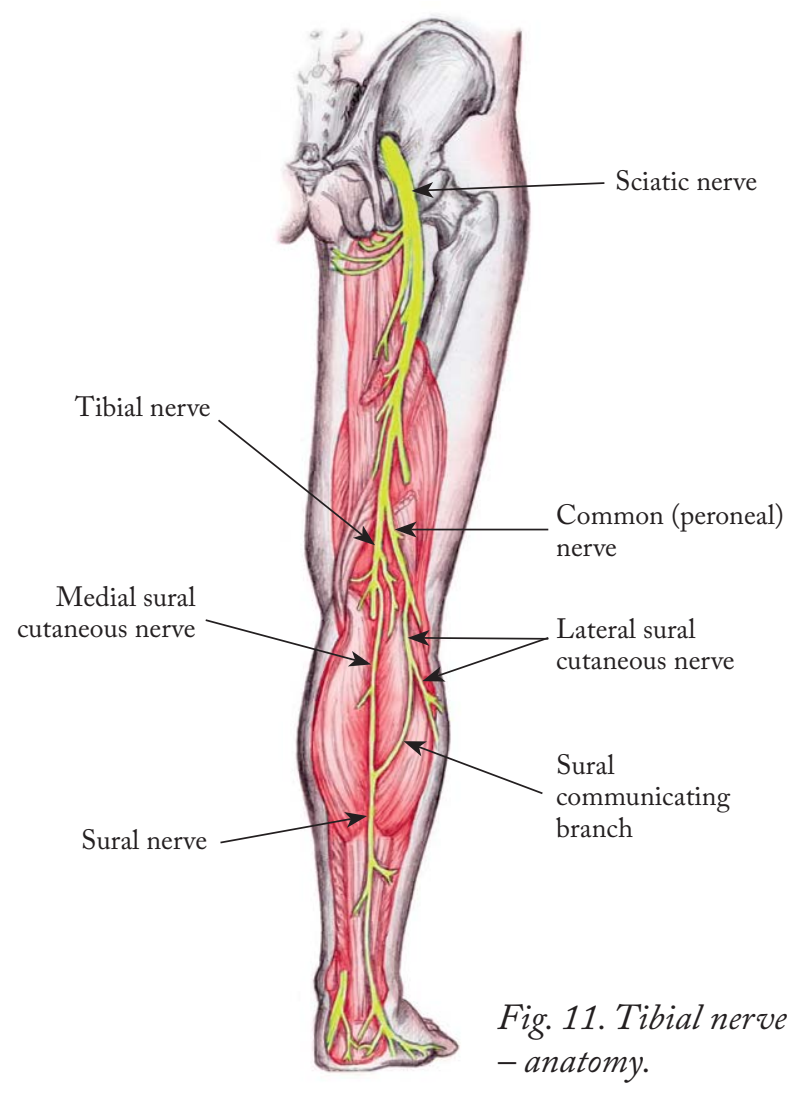

canal syndrome) is caused by prolonged sitting on bicycle seat (cyclists). Clinical signs are pain in the pelvis, frequent micturition, genital pain, rarely urinary incontinence, and partial erectile dysfunction (male). The symptoms disappear quickly and rarely persist for weeks or months. Somatosensory evoked potentials can be used in diagnosis. The finding of prolonged latency indicates nerve damage. Treatment involves rest and biomechanical analysis of the bicycle seat ${ }^{24}$.

\section{Conclusion}

Peripheral nerve injuries in sports are rare. They occur as a result of acute injuries. Chronic injuries are overuse injuries or the result of muscle and joint damage, rarely as a result of inappropriate sports equipment. Treatment involves physical therapy, analysis of nerve injury mechanisms, and occasionally surgical treatment.

\section{References}

1. Hirasawa Y, Sakakida K. Sports and peripheral nerve injury. Am J Sports Med.1983 Nov-Dec;11(6):420-6. 
2. Rasulić L, Puzović V, Rotim K, Jovanović M, Samardžić M, Živković B, Savić A. The epidemiology of forearm nerve injuries - a retrospective study. Acta Clin Croat. 2015 March; 54:17-24. 3.

3. Seddon HJ. Three types of nerve injury. Brain.1943 Dec;66 (4):237-88.

4. Krivickas LS. Anatomical factors associated with overuse sports injuries. Sports Med.1997 Aug;24(2):132-46.

5. Lorenz DS, Reiman MP, Walker JC. Periodization - current review and suggested implementation for athletic rehabilitation. Sports Health. 2010 Nov;2(6):509-18.

6. Quan D, Bird JS. Nerve conduction studies and electromyography in the evaluation of peripheral nerve injuries. UPOJ. 1999;12:45-51.

7. Mitchell CH, Brushant TM, Shivani A, Belzberg AJ, Corrino JA, Fayad LM. MRI of sports-related peripheral nerve injuries. AJR Am J Roentgenol. 2014 Nov;203(5):1075-84.

8. Wiesler ER, Chloros GD, Cartwright MS, et al. Ultrasound in the diagnosis of ulnar neuropathy at the cubital tunnel. J Hand Surg Am. 2006 Sep;31(7):1088-93.

9. Safran MR. Nerve injury about the shoulder in athletes. Part 2: Long thoracic nerve, spinal accessory nerve, burners/stingers, thoracic outlet syndrome. Am J Sports Med. 2004 June;32 (4):1063-76.

10. Safran MR. Nerve injury about the shoulder in athletes. Part 1: Suprascapular nerve and axillary nerve. Am J Sports Med. 2004 Apr-May;32(3):803-19.

11. Lorei MP, Hershman EB. Peripheral nerve injuries in athletes: treatment and prevention. Sports Med. 1993 Aug;16(2): 130-47.

12. Morris HH, Peters BH. Pronator syndrome: clinical and elecrophysiological features in seven cases. J Neurol Neurosurg Psychiatry. 1976 May;39(5):461-4.
13. Kimura J. The carpal tunnel syndrome. Localisation of conduction abnormalities within the distal segment of the median nerve. Brain. 1979 Sep;102(3):619-35.14.

14. Hazani R, Engineer NJ, Mowlavi A, et al. Anatomic landmarks for the radial tunnel. ePlasty. 2008 Jun;22(8):e37.

15. Toth C. Peripheral nerve injuries attributable to sports and recreation. Phys Med Rehabil Clin N Am. 2009 Feb;20(1): 77-100.

16. Khalil N, Nicotra A, Rakowicz W. Treatment for meralgia paraesthetica. Cohrane Database Syst Rev. 2008 Jul;16(3): CD004159.

17. Kuntzer T, van Melle G, Regli F. Clinical and prognostic features in unilateral femoral neuropathies. Muscle Nerve. 1997 Feb;20:205-11.

18. Hertel J. Functional instability following lateral ankle sprain. Sports Med. 2000 May;29(5):361-71.

19. Leach RE, Purnell MB, Saito A. Peroneal nerve entrapment in runners. AM J Sports Med. 1989 Mar-Apr;17(2):287-91. 20.

20. Tucker AK. Chronic exertional compartment syndrome of the leg. Curr Rev Musculoskelet Med. 2010 Sep;2;3(1-4):32-7, http://dx.doi.org/1007/s12178-010-9065-4.

21. Diebal AR, Gregory A, Alitz C, Gerber JP. Effects of forefoot running on chronic exertional compartment syndrome: a case series. Int J Sports Phys Ther. 2011 Dec;6(4):312-21.

22. Kinoshita M, Okuda R, Yasuda T, Abe M. Tarsal tunnel syndrome in athletes. Am J Sports Med. 2006 Aug;34(8):1307-12.

23. Antoniadis G, Schelgmann K. Posterior tarsal tunnel syndrome: diagnosis and treatment. Dtsch Arztebl Int. 2008 Nov; 105(45):776-81.

24. Weiss BD. Clinical syndrome associated with bicycle seats. Clin Sports Med. 1994 Jan;13(1):175-86.

Sažetak

\section{OZLJEDE PERIFERNIH ŽIVACA U SPORTU}

\section{B. Radić, P. Radić i D. Duraković}

Periferni živci u sportaša osjetlivi su na ozljede zbog porasta fizioloških zahtjeva na neurološke strukture i meka tkiva koja ih štite. Zajednički mehanizam ozljede su pritisak, istezanje, ishemija i ozljeda. Seddonov izvorni sustav podjele ozljeda živaca na temelju neurofizioloških promjena najšire se primjenjuje. Prvi stupanj ozljede živca je neurapraksija, drugi stupanj je aksonska degeneracija, a treći stupanj je presijecanje živca. Ozljede perifernih živaca češće su na gornjim udovima nego na donjim udovima, imaju osobitosti vezane za određenu vrstu sporta, a često imaju biomehaničku komponentu u nastanku. Rano otkrivanje omogućuje pokretanje odgovarajućeg programa rehabilitacije i promjenu biomehanike prije nego ozljeda živca postane trajna. Prepoznavanje ozljeda živaca zahtijeva razumijevanje periferne neuroanatomije, poznavanje uobičajenih mjesta ozljede živaca i svijest o vrstama ozljeda perifernih živaca koje su zajedničke i jedinstvene za svaki sport. U postavljanju dijagnoze ozljeda perifernih živaca primjenjuju se elektrodijagnostički test (elektromiografija), somatosenzorni evocirani potencijali, magnetska rezonanca i ultrazvuk. Proksimalne ozljede perifernih živaca imaju lošiju prognozu u smislu neurološkog oporavka.

Ključne riječi: Sport; Periferni živci, ozljede; Dijagnostika; Prijelomi, kost; Trauma, živčani sustav 